\author{
Alicja Tupieka-Buszmak \\ Uniwersytet Warmińsko-Mazurski w Olsztynie \\ E-MAIL: alabuszmak@wp.pl
}

\title{
Konsumpcjonizm w kulturze i edukacji muzycznej. Zarys problematyki i wymiaru zjawiska
}

\begin{abstract}
STRESZCZENIE
Klasyczne ujmowanie definicji kultury muzycznej, tak w socjologii, estetyce czy edukacji wskazuje na pewną lukę wobec narastających zjawisk kultury popularnej. Według przedstawicieli nurtu myśli krytycznej dość wyraźnie rysuje się obraz charakterystycznych symptomów kultury współczesnej, wśród których podstawowym wyznacznikiem wydaje się (niespotykane dotąd) oblicze konsumpcjonizmu. Niestety, ta niekorzystna praktyka społeczna zawłaszcza także obszar edukacji muzycznej, najbardziej uwidoczniony w powszechnym wymiarze kształcenia. Konsumpcja oznacza tu fragmentaryczne, powierzchowne i z różnych względów upozorowane działania pedagogiczne na rzecz trwałego uwypuklenia kultury wysokiej, przy jednoczesnym braku świadomości nieprzystawalności tradycyjnych treści, metod, a także form wychowania muzycznego do współczesnego świata oraz tego, jak odbierają i czym żyją młodzi ludzie. O swoistym niezrozumieniu problemu świadczą m.in. tematy publikacji, dyskusji i konferencji poświęconych tematyce muzycznej. Artykuł stanowi subiektywny (oparty jednakże na wieloletnim, poddanym autorefleksji doświadczeniu pedagogicznym w różnych ośrodkach kształcenia) rys krytycznej analizy sytuacji, w jakiej znajduje się powszechna edukacja muzyczna, a jego celem jest odkrycie ewentualnych dróg i ukierunkowanie przyszłych działań w tym zakresie.
\end{abstract}

SŁOWA KLUCZOWE: kultura, konsumpcja, muzyka, edukacja.

\section{Wprowadzenie. Zagadnienia podstawowe}

Kultura jako całokształt dorobku ludzkości, gromadzony, utrwalany i nieustanie przekształcany $w$ różnych przejawach życia społecznego, jest jak powietrze. Nie sposób wyobrazić sobie bez kultury człowieka (filozofia, nauka, sztuka, prawo, religia, język), ale też trudno odnaleźć w powszechnym obrazie bieżącej ludzkiej aktywności jakiś szczególny rodzaj refleksji nad kulturą, a zwłaszcza jej przemianami. W świadomości zbiorowej kultura dopiero wtedy uzyskuje pewien stopień widoczności, kiedy w polu ludzkiej percepcji do głosu dochodzą alternatywne, budzące opór bądź zdumienie, praktyki społeczne. I właśnie one najczęściej zapoczątkowują łańcuch mniej lub bardziej gwałtownych zmian, przyczyniając się do swoistego tąpnięcia monolitu 
tożsamości kulturowej społeczeństwa, danej grupy czy generacji (Sztompka, 2012, s. 294). Jednym z aspektów kultury niematerialnej, w której ten właśnie rodzaj pęknięcia bodaj najbardziej jest zauważalny - wydaje się kultura estetyczna, stanowiąca bazę dla kultury i edukacji muzycznej.

Niniejszy artykuł jest skromną próbą zmierzenia się z muzycznymi wyznacznikami trwałości oraz zmiany wedukacji w kontekście tradycyjnego i postmodernistycznego rozumienia kultury muzycznej, wartościującego oraz interpretatywnego modelu kształcenia w tym zakresie, a także nieuchronnego zderzenia klasycznej „paidei” ze współczesnymi realiami przemian kulturowych, wśród których konsumpcjonizm stanowi jeden z czołowych komponentów. Celem artykułu jest rozpoznanie tego zjawiska w przestrzeni muzycznej, określenie jego podstawowych sygnałów, a także próba stworzenia wstępnej propozycji możliwych do przyjęcia kierunków działania, które, choć częściowo, zniwelowałyby skutki myślenia o sztuce i edukacji w kategoriach popytu - podaży, a także konieczności konsumowania wielu fragmentarycznych wrażeń i czynności o domniemanych jedynie walorach estetycznych. Te z kolei mistyfikują przemyślaną strategię aktywności edukacyjnej, której deklarowanym wszak od lat postulatem pozostaje uwrażliwianie na wartości tkwiące w przedmiotach estetycznych, szeroko pojętych dobrach kultury, kształtowanie kompetencji percepcyjno-ekspresyjnych oraz pogłębianie potrzeby aktywnego współuczestnictwa w kulturze muzycznej, w powiązaniu $\mathrm{z}$ uniwersum humanistycznych wartości oraz postaw (Przychodzińska, 2006; Konaszkiewicz, 2012; Sacher, 2012). Aby uchwycić zjawisko konsumpcjonizmu w strefie kształcenia muzycznego, sformułowałam kilka podstawowych problemów, które przybrały formę następujących pytań:

- w jakim wymiarze konsumpcjonizm jako wyraźny wyznacznik współczesnej kultury przenika również do edukacji?

- jakie cechy bądź symptomy tego zjawiska w edukacji muzycznej można uznać za przejaw konsumpcjonizmu?

- co dla uczniów i nauczycieli oraz sposobu postrzegania muzyki w praktyce szkolnej (zmarginalizowanej do funkcji tzw. „michałka” w odniesieniu do innych obszarów kształcenia) wynika z takiego obrazu doświadczania sztuki i kultury muzycznej?

Posługując się terminem „edukacja muzyczna” mam na myśli powszechny, a nie specjalistyczny wymiar kształcenia w zakresie muzyki, realizowany $\mathrm{w}$ formie przedmiotu w szkolnictwie podstawowym i ponadpodstawowym oraz pozalekcyjnych formach aktywności, typu: interdyscyplinarne zajęcia artystyczne, warsztaty i zespoły muzyczne, studio piosenki, nauka podstaw 
gry na danym instrumencie itp. ${ }^{1}$ Artystyczne szkolnictwo muzyczne dotyczy bowiem wybranej grupy młodzieży, o zweryfikowanych predyspozycjach muzycznych i ukierunkowanych zainteresowaniach. Oczywiście i ono natrafia na problemy, ale są one innego typu.

Przez kulturę estetyczną rozumiemy jedną z możliwości holistycznego rozwoju człowieka, polegającego na kształtowaniu jego osobowości, kompetencji poznawczych, moralnych i społecznych w kontakcie ze sztuką, jej percepcją i przeżyciem, a także własną twórczością artystyczną oraz stylem i poziomem aspiracji (Gołaszewska, 1979, s. 5 i n.). To klasyczne ujęcie kultury estetycznej uwypukla wymóg hierarchizowania zarówno wytworów sztuki, tzn. takich dóbr, które mogą być do nich zaliczone, jak i form aktywności czy kontaktu ze sztuką, według kryterium ich artystycznego poziomu oraz spektrum wartości (np. afirmacyjnych, estetycznych, poznawczych, wychowawczych). Nieco inne spojrzenie na kulturę symboliczną, w tym też na kulturę estetyczną, prezentuje antropologia kulturowa. Według antropologów należy zrezygnować z opozycyjnego podziału kultury na wysoką, czyli prawdziwą, oraz niską, tj. popularną. Taka retoryka prowadzi do uproszczonego przekonania, że im mniej zrozumienia w społeczeństwie dla tej pierwszej, tym więcej przestrzeni zawłaszcza druga. W ujęciu antropologicznym kulturą nazywa się wszystko, co należy do społecznie uregulowanego sposobu życia, a to, że jest on zmienny i uzależniony od kontekstu - to już inna kwestia (Burszta, 1998, s. 40 i n.). W myśl dychotomicznego podziału kultury gust czy smak estetyczny byłby automatycznie rezerwowany dla jednowymiarowych odbiorców którejś z grup, natomiast sfera doznań, zainteresowań i upodobań estetycznych zdaje się znacznie bardziej złożona. Swoistym kontekstem w kulturze estetycznej jest specyfika samej subdyscypliny zogniskowanej wokół tego, co się uważa za piękne, oryginalne i poruszające, ewolucja w ujmowaniu i klasyfikowaniu wypowiedzi artystycznej oraz nasza na nią reakcja. W podobnym klimacie wypowiada się Władysław Tatarkiewicz, postulując rezygnację z usztywnionej definicji sztuki na rzecz szerokiego uznania jej za formy i przejawy odtwarzania, konstruowania bądź wyrażania przeżyć, jeśli tylko potrafią one zachwycać, wzruszać lub wstrząsać (Tatarkiewicz, 1975, s. 52).

Na tego typu formy zajęć, oferowanych uczniom w różnych typach olsztyńskich szkół, natknęłam się jako wieloletni koordynator praktyk studenckich na kierunku „Edukacja artystyczna w zakresie sztuki muzycznej”, chociaż oczywiście nie wyczerpują one innych sposobów kontaktu z muzyką. 


\section{Przemiany w kulturze a społeczny obraz muzyki}

Jednowymiarowy sposób postrzegania kultury przenika również do edukacji artystycznej, nie pozostawiając zbyt wiele miejsca na namysł, dyskusję, racjonalnie argumentowany dyskurs. Edukacja muzyczna opierająca się na wartościach estetycznych i takich praktykach celowego oddziaływania, w których uznaje się, iż doświadczanie artystyczne i świadomy kontakt z różnymi przejawami sztuki stanowi niezastąpione narzędzie rozwoju człowieka - również ulega przemianom (Białkowski, 2012). Kierunek, dynamika oraz zakres zmian zachodzących w kulturze muzycznej wydają się drążyć i edukację, stanowiąc przesunięte w czasie, ale nawarstwiające się, i dlatego też zniekształcone, ich odbicie. Widocznym dla socjologów zjawiskiem w domenie tzw. dźwiękosfery jest np. powszechna indywidualizacja muzycznych praktyk, wszechobecność dźwiękowych figur we wszystkich aspektach życia, przy jednoczesnym zubożeniu pierwiastka społecznego i intelektualnego muzyki (dotyczy funkcji integracyjnej, ludycznej, tożsamościowej), odpowiadającego m.in. za komunikacyjne możliwości muzyki (Jabłońska, 2014, s. 136). Problem tkwi również $\mathrm{w}$ tym, że potoczny odbiór zachodzących zmian jest rozproszony, słabo artykułowany i niejasny, tak jakby edukacyjne praktyki przygotowujące do percepcji i ekspresji artystycznej poprzez muzykę przygotowywały do odbioru niezmiennych zjawisk estetycznych, w takim świecie i wedle takich reguł, które są stałe. Niestety, dzieje się inaczej. Utarte szlaki postrzegania treści i sposobów ich realizacji w czystej formie już nie przystają, bądź - co najmniej - nie są jedyne. Dlatego też analiza współczesnego społeczeństwa, uwikłanego i generującego równocześnie przemiany zachodzące w kulturze, wydaje się warunkiem analizy obrazu edukacji muzycznej.

Według obserwatorów życia społecznego i przedstawicieli myśli krytycznej, charakterystycznymi cechami współczesnego świata i procesów „toczących" społeczeństwo są dające się ująć w następujące hasła: kultura konsumpcji, prymat zmiany i szybkiego życia, rezygnacja z wysiłku w samodoskonaleniu na rzecz triumfu „rozpychającej się” codzienności, kultura upozorowanej mocy, a także powierzchownej wolności, kult ciała i sukcesu, postępująca globalizacja i umasowienie bez mała wszystkich sektorów kultury, wrogość, brak woli i umiejętności porozumienia rywalizujących ze sobą grup oraz kultur społecznych (Melosik, 2007, s. 68 i n.; Melosik, 2013, s. 16 i n.). Pierre Bourdieu, proponując klasowe spojrzenie na społeczeństwo oraz praktyki umacniania nierówności (m.in. poprzez narzucanie przez warstwę panującą uprawomocnionej kultury), odnosi się również do pola sztuki jako przestrzeni relacji pomiędzy pozycjami społecznymi, wyznaczanymi m.in. percepcją określonej muzyki i muzycznym gustem estetycznym. Nabyty 
w procesie socjalizacji, także w toku działania szkoły, zespół nawyków mentalnych i sposobów myślenia o sobie w kontekście sztuki, w niemałym stopniu wyznacza społecznie ukształtowane preferencje estetyczne, a te z kolei ugruntowują sposoby korzystania z dóbr kultury. Przyczynia się to do utorowania pewnych praktyk w zakresie doświadczenia muzyki. Kapitał szkolny wraz z kapitałem rodzinnym jeszcze mocniej uwypukla podział w dystrybucji możliwości estetycznych, typu: gust luksusowy, przynależny elitom, oraz gust masowy - wybrany z konieczności, a będący pochodną społecznej marginalizacji czy zaniedbania (Bourdieu, 2005, s. 40-43, 74-75, 217-218).

Z tezą tą, przynajmniej tą jej częścią, która dotyczy społecznie zdeterminowanych preferencji muzycznych, nie zgadza się Zbyszko Melosik. Ze względu na fakt, iż kultura popularna obejmuje coraz szersze dziedziny działalności człowieka i coraz większe zróżnicowanie form, a powszechne w niej uczestnictwo nie tylko nikogo nie dziwi, ale wręcz nobilituje. Banalne motywy muzyczne aranżowane są przez artystów na profesjonalne zespoły instrumentalne, rekordy popularności biją programy telewizyjne opierające się na prostej muzyce i promowaniu nowych gwiazd popkultury, doskonale wykształceni muzycy klasyczni towarzyszą na scenie piosenkarzom, a niekiedy wręcz tzw. celebrytom. W tych warunkach nikt już nie wie - kto jest mistrzem, a kto czeladnikiem..., a może nie jest to w ogóle istotne. Również jedna i ta sama osoba mieści w sobie odmienne upodobania muzyczne, w zależności od potrzeby/pełnionej roli społecznej, sięgając po arię operową, muzykę symfoniczną, klasykę jazzu czy rocka. Nawet znienawidzone przez krytyków disco polo ma zagorzałych słuchaczy i obrońców tego typu rozrywki. Problem polega na wszystkożerności, w myśl zasady: im więcej, tym lepiej (Melosik, 2013, s. 46-47).

Ulrich Beck, stojąc na gruncie teorii społecznej i diagnozy kultury, wiąże współczesne stadium nowoczesności jeszcze z czymś innym, a mianowicie z nastaniem społeczeństwa ryzyka. Dobra wytwarzane niegdyś przez społeczeństwo przemysłowe sieją zagrożenie, gdyż drastycznie przeważyły nad rozwojem, dającym poczucie bezpieczeństwa. Zmiany zachodzące w kulturze, w galopującym tempie podkopują wszystkie fundamenty, na których została zbudowana nasza cywilizacja, a etap, w którym postęp przemienia się w globalne samozniszczenie, Beck nazywa stadium modernizacji refleksywnej. Skutkami tego zjawiska są: stały, trudny do zdefiniowania lęk pośrednio zobrazowany w skrajnym przepychu nielicznych i ubóstwie przeważającej populacji globu, odradzającym się nacjonalizmie, fundamentalizmie religijnym, kryzysie gospodarczym, politycznym i ekologicznym, niekontrolowanych ruchach migracyjnych itp. Nieustanne mnożenie ryzyk prowadzi do unie- 
ważnienia wszelkich znanych nam zasad porządku. Na tym też polega efekt złudzenia społecznego bezpieczeństwa, że mając możliwość dokonywania wyboru z coraz większej oferty produktów i kompulsywnych zachowań, tak naprawdę nie mamy wpływu na jakiekolwiek ostateczne rozwiązania (Beck, 2009, s. 21-26). Co ciekawe, wiedza i doświadczenie przepływają nie tylko przez kanały informacyjno-komunikacyjne, ale również za pośrednictwem znaków konwencjonalnych, z których dźwięk wydaje się znamiennym symbolem tzw. refleksyjności estetycznej. Miło brzmiący termin (refleksyjność estetyczna), niestety, nie dotyczy podmiotów, a przedmiotów wykreowanych przez przemysł kulturalny. Przedmioty te nabywają swoją refleksyjność, gdyż stanowią własność bogatą w symbole, są utorowane i reklamowane. W tym kontekście refleksyjność przedmiotów przemysłu kulturalnego wypiera refleksyjność obiektów kultury. Dlatego też przemysł kulturalny (a zwłaszcza telewizja) właśnie poprzez muzykę w coraz większym stopniu identyfikuje całą gamę produktów, usług, własności - pozornie z nią niezwiązanych. Problem kultury popularnej tkwi w jej usankcjonowaniu i upodobnieniu do kultury wysokiej w tym sensie, że przestała ona pełnić funkcję oporu, a przejęła atrybut dominacji. Przedmioty kulturowe mogą być ponadto wykorzystywane do walki o klienta, mistyfikując nieograniczoną wolność w podejmowaniu decyzji, która zasadza się na buncie przeciw dominacji. Typ refleksyjności estetycznej cechuje się mocną artykulacją „ja” pragnącego, opartego na ekspresywnym indywidualizmie i niezobowiązującym wyborze wielu niepowiązanych ze sobą zdarzeń (Lash, 2009, s. 177, 182-183, 210).

Zygmunt Bauman w konsumpcjonizmie doby postmodernizmu upatruje czegoś bardziej niebezpiecznego, niż tylko lekkomyślny, powierzchowny styl życia. Chodzi bowiem o takie zasady kreowania ról społecznych, które pozwalają obywatelom wchłaniać mentalność konsumenta, skutecznie wypłukując ich zdolności interpretatywne do definiowania sytuacji. Zatem gra, w którą „wplątany” jest konsument, to już nie tylko żądza nabywania i posiadania czegoś konkretnego, ale wzbudzanie spotęgowanych emocji, zaś kolekcjonowanie ich ekwiwalentu jest tego pochodną. Konsumenci wchodząc w tę toksyczną „zabawę” sami poszukują okazji, aby ich uwieść kolejną atrakcją i przynętą. Konsumpcyjny cykl życia - rozgrywany od wrażenia do wrażenia - staje się oficjalnym stylem bycia, pozorując dobrostan i wspólnotę porozumienia, lecz w zasadzie tępi wolę i wysiłek w odnalezieniu życiowego celu, opartego na prawdziwych relacjach międzyludzkich (Bauman, 2008, s. 13 i n.).

W społeczeństwie ponowoczesnym potrzeby konsumentów, dawniej ograniczone do określonych towarów i usług, zostały przekształcone w permanen- 
tne zjawisko konsumpcjonizmu, które polega na generowaniu absurdalnych pragnień w zakresie posiadania. Atrybut posiadania to archetyp władzy oraz symbol znaczący, np. wykształcenia, prestiżu, przynależności do grupy osób, o takim statusie czy wizerunku, z którym się ktoś identyfikuje bądź chciałby, aby inni aktorzy społeczni go utożsamiali. Nadmierne otaczanie się rozmaitymi rekwizytami jest formą fasady i stanowi zewnętrzny substytut dowartościowania (Goffman, 2011; Blumer, 2008). Problem tkwi jednak w swoistym zapętleniu współczesnego człowieka, które przejawia się tym, że cokolwiek nabędzie - uzyskany stan szczęśliwości trwa chwilę, rozchodząc się w dwóch kierunkach: poczucia pustki i rozczarowania, z jednoczesnym imperatywem skupienia uwagi na innym obiekcie pragnień. Zbyszko Melosik nazwał ten stan schizofrenicznością kultury konsumpcyjnej, charakteryzującą się niebywałą szybkością spiralnego ruchu pozornej aktywności, która mimowolnie przekierowuje uwagę konsumenta ku nowym zdobyczom, zanim starsze w ogóle zostaną skonsumowane (Melosik, 2007, s. 71). Przymus bezrefleksyjnego gromadzenia dóbr przenosi się w sferę kolekcjonowania wrażeń, tak jednak ulotnych, że kolekcja ta - z punktu widzenia konsumenta - zawsze świeci pustkami. Koncerny handlowe (w tym przemysł muzyczny) usprawiedliwiają tę tendencję prawem do wzbogacenia doświadczenia, które skutecznie starają się zaspokoić. W istocie jednak - nieustannie podtrzymywać, a następnie wzmagać. Temu mechanizmowi wydaje się ulegać również kultura i edukacja muzyczna.

\section{Konsumpcjonizm w kulturze i edukacji muzycznej}

Widocznym problemem we współczesnej kulturze, ale też edukacji muzycznej, związanym z konsumpcjonizmem wydaje się marginalizowanie wysiłku poznawczego, służącego analizie i interpretacji zjawisk estetycznych czy ukierunkowaniu doznań towarzyszących percepcji. Niekiedy te ostatnie z estetyką niewiele mają wspólnego. Rzecz bowiem nie tyle we wrażliwości czy upodobaniach repertuarowych słuchacza/odbiorcy/wykonawcy, bo te zawsze będą dyskusyjne, ile w tendencyjnym, uproszczonym, niepoddanym racjonalnej argumentacji wyborze, imitującym samodzielność i niepowtarzalność. Z mitem niepowtarzalności sprzyjającej poczuciu wolności i indywidualizmu rozprawia się Yoriko Terada, uznając, iż w pogoni za wyróżniającą nas z tła odrębnością, rozpaczliwie szukamy własnej tożsamości. Członkowie społeczeństwa ponowoczesnego, w tym uczniowie, ich rodzice i nauczyciele, jak ze sklepowego wieszaka nabywają, wymieniają bądź zbywają różne tożsamości, ucharakteryzowane tylko na własne. W tych zabiegach paradoksalnie stają się upodobnieni, tyle że działając w samotności nie mają 
wiedzy o tym, czemu ulegają. Współcześni konsumenci zachłyśnięci możliwością rozpoczynania wszystkiego od nowa, wpadają w retorykę ucieczki od prawdziwej rzeczywistości, realnych problemów, zaś kalejdoskop kolorowych produktów, usług, wrażeń czyni tę ucieczkę ekstremalnie atrakcyjną (Terada, 2004, s. 12, 19-21).

Tak rozumiane zjawisko konsumpcjonizmu dotyka także obszaru edukacji muzycznej. Obraz kultury współczesnej i nabrzmiałe w niej problemy wkraczają w mikroświat szkoły oraz wiedzy o szkole. Dlatego nie można ich wypierać i od nich abstrahować. Kultura, ani ta nasycona wymiarem estetycznym, ani też ta związana z pracą i zawodem nauczyciela, nie jest zawieszona w próżni i nie rozgrywa się w kontrolowanych warunkach laboratoryjnych. Konsumpcja oznacza tu fragmentaryczne, powierzchowne, $\mathrm{z}$ różnych względów upozorowane działania pedagogiczne na rzecz konieczności realizacji programu nauczania, uwypuklenia sztandarowych treści uprawomocnionej tradycją kultury, przy jednoczesnym braku świadomości nt. nieprzystawalności wyeksploatowanych tematów, metod, a także form wychowania muzycznego do tego, jak odbierają i czym obecnie żyją młodzi ludzie. Fałsz w edukacji, czego dowodzi Maria Dudzikowa, można analizować biorąc pod uwagę kryterium czterech mechanizmów działań pozornych autorstwa Jana Lutyńskiego. Jest to mechanizm organizacyjno-decyzyjny (kryjący się w strukturze instytucji i systemie podejmowania decyzji), mechanizm aksjologiczny (odwołujący się do szczytnych wartości, które się co prawda głosi, ale którymi się manipuluje i de facto - nie realizuje), mechanizm obowiązkowego wykonawstwa nieżyciowych rozporządzeń (wynikający z rozdętej biurokratyzacji i wszechobecnej władzy administracyjnej), mechanizm rzekomo-pragmatyczny (sprawiający jedynie wrażenie podejmowania skutecznych, ukierunkowanych działań skierowanych na rozwiązanie ważnego społecznie problemu). W przestrzeni edukacyjnej wszystkie z mechanizmów występują równolegle, nakładając się na siebie i wzajemnie warunkując, jednak centralnym wydaje się mechanizm organizacyjno-decyzyjny, w dalszej kolejności mechanizm aksjologiczny, a następnie mechanizm rzekomo-pragmatyczny i obowiązkowo-wykonawczy (Dudzikowa, 2013, s. 34). Sfera edukacji muzycznej jest równie „nasączona” działaniami pozornymi, a o swoistym niedostrzeganiu problemu świadczą m.in. tytuły publikacji, tematy konferencji i kuluarowych dyskusji poświęcone tematyce muzycznej². Z uporem,

2 Przytaczając nieliczne tu przykłady tematyki współczesnych dyskusji akademickich, dotyczących edukacji muzycznej (m.in. „Wychowawcze funkcje muzyki w badaniach pedagogicznych”; „Psychologiczne teorie rozwoju muzycznego dziecka”; „Charakterystyka studentów wychowania muzycznego w poszczególnych ośrodkach akademickich”; „Funkcje 
choć z rzadkimi głosami sprzeciwu, eksponują one zamknięty krąg powielanej i oczywistej bądź nieprzystającej do realiów współczesnego świata problematyki. Ta ostatnia dotyczy ilościowego mnożenia zawodowych kompetencji oraz zadań nauczyciela muzyki, psychopedagogicznych uwarunkowań rozwoju muzycznego dziecka, przyczyn zapaści powszechnej edukacji muzycznej, diagnozowanych co jakiś czas testami wiedzy o muzyce i podstawowymi umiejętnościami w tym zakresie. Poza kontestacją, jak bardzo jest źle, i skupieniem uwagi na bezpośrednio namacalnych czynnikach tego stanu rzeczy, typu: przeładowane klasy, słabe wyposażenie sal, niedobre przygotowanie do zawodu, „głuche” pokolenie, społeczne zmarginalizowanie roli sztuki i samego nauczyciela $\mathrm{w}$ wychowaniu, wypalenie zawodowe, niskie wynagrodzenie itp., z trudem przebijają się tematy poświęcone pogłębionej analizie opisywanych faktów, zakorzenione w globalnych przemianach kultury3. Oczywiście dobrze, iż przedstawiciele środowiska nauczycieli/badaczy pedagogiki muzyki w ogóle pragną się spotykać i ze sobą dyskutować, ale ograniczanie się do powierzchownej penetracji obserwowanych zjawisk i kosmetycznych udoskonaleń prowadzenia zajęć, wobec i tak zmieniającej się rzeczywistości - to za mało.

W edukacji muzycznej konsumentami są zarówno nauczyciele, jak i decydenci systemu oświaty, pracownicy instytucji edukacyjnych, jednostek ewaluacyjnych itp. Jedni konsumują podstawiane im produkty edukacyjne, inni procedury wychwycenia i wyceny efektów kształcenia, ale jedni i drudzy „kupują" pewną wizję modelu wiedzy i procesu kształcenia, sposób zdobywania, utrwalania i operowania umiejętnościami, a także standardy pełnionych ról. Inną grupę konsumentów stanowią uczniowie, ich rodzice i ogólnie - społeczeństwo, przekonane o takiej istocie rozwoju, w którego centrum znajdują się nowinki, wszelkie praktyki uprzedmiotowionego traktowania i egzekwowania wiedzy, zdobywanych sprawności itp. Żeby stanowisko takie utrzymać, koncerny skupione wokół resortu szkolnictwa (i nie tylko) spryt-

i zadania ucznia i nauczyciela w edukacji muzycznej”; „Aksjologiczne podstawy pedagogiki muzyki”; „Metodyka muzyki w edukacji szkolnej” itp.) nie chcę piętnować jakiegokolwiek środowiska ani niweczyć wysiłku organizacji takich spotkań. Wybór jednakże znanego już z literatury, a „statycznego" problemowo, spektrum poruszanych zagadnień wskazuje, moim zdaniem, na pewną lukę w dostrzeganiu złożonych uwarunkowań powszechnego kształcenia muzycznego i dogłębnej, być może nawet radykalnej w swej krytyce, analizy zastanej i nieustannie zmieniającej się rzeczywistości społeczno-kulturowej.

3 Opis zaistniałych sytuacji z pewnością nie oddaje ani charakteru, ani obrazu całej edukacji muzycznej. Jest natomiast wynikiem mojego wieloletniego doświadczenia - jako animatora działań kulturalnych, nauczyciela muzyki, koordynatora przedmiotów metodycznych - w różnych środowiskach i poziomach edukacji, które nieustannie poddaję konfrontacji i autorefleksji. 
nie wkomponowują w świadomość społeczną konieczność nabywania dodatkowych gadżetów w postaci pakietów edukacyjnych, korepetycji, stymulujących rozwój dziecka zajęć itp. Oczywiście problem nie tkwi w samych dodatkowych zajęciach, środkach czy narzędziach dydaktycznych, ale w obdarzaniu ich nieuzasadnioną atencją na niekorzyść tego, co w procesie kształcenia istotne. Na poziomie dóbr materialnych handluje się np. ofertą wydawniczą, tzn. podręcznikami z bonusem od wydawnictwa, dodatkowymi materiałami edukacyjnymi, planszami edukacyjnymi, przewodnikiem metodycznym (przypominającym bardziej zbiór scenariuszy prowadzenia lekcji, niż uporządkowaną, inspirującą do samodzielnego myślenia pomoc), pakietem płyt CD z - nie zawsze na odpowiednim poziomie - nagraniami utworów do wykonania, zaproszeniami na daną imprezę kulturalną, bezpłatnym kursem czy szkoleniem metodycznym, niestety, nakierowanym ideologicznie na „jedyny w swoim rodzaju”, „rewelacyjny”, „niezwykle skuteczny” produkt.

\section{Propozycje}

W dzisiejszych czasach naznaczonych konsumpcjonizmem i złożonym, interakcyjnym kontekstem zmian kulturowych, prócz podręcznego warsztatu zawodowego, który jest niezbędny, ale absolutnie już nie wystarcza, potrzebna jest wola podmiotowego (choć niekoniecznie indywidualnego) analizowania interesujących i budzących zainteresowanie zjawisk ${ }^{4}$. Koniecznym wydaje się trud ustanawiania i aktualizowanego celu, a służącym mu formom percepcji i aktywności artystycznej - podzielone nadawanie znaczeń z poszanowaniem innego stanowiska, również w celach projakościowych (poprzez krytyczne spojrzenia na własne racje). W moim odczuciu możliwe jest takie rozumienie edukacji, które - zachowując istotę sztuki muzycznej - dałoby się powiązać z możliwościami percepcyjnymi, osobistymi preferencjami oraz doświadczeniem dziecka, co w konsekwencji doprowadziłoby do odważniejszego, zdecydowanie bardziej elastycznego doboru treści i proponowanych/uzgadnianych sposobów kontaktu z muzyką. Nie sądzę, aby przy wzajemnym, nieustannie podsycanym zainteresowaniu podmiotów muzycznej przestrzeni edukacyjnej, groźba pozostania na tych najprostszych i najbardziej powierzchownych, byłaby powszechna.

Wychowanie do wartości i szacunku do tradycji nie zamyka się przecież w monotypii przekazu estetycznego. Może wnieść także inne konteksty

4 Obraz współczesnej szkoły z podporządkowanym nauczycielem, sprowadzonym do roli wykonawcy wymuszonych (zwłaszcza programowo-metodycznych) wytycznych ministerialnych, doskonale przytaczają m.in. Dorota Klus-Stańska i Marzena Nowicka (Klus-Stańska, Nowicka, 2005, s. 7-8). 
interpretacji. Wybrane i zaakceptowane działania ekspresyjne czy około-muzyczne (m.in. drama, gry miejskie, sztuka w interakcjach) mogłyby z kolei służyć przezwyciężeniu marazmu i usensownieniu szkolnego życia kulturalnego. Powszechna edukacja muzyczna nie musi ślepo podążać za zmianami zachodzącymi w kulturze, bo nie zawsze są one tego warte, ale nie może ich ignorować. Dlatego też świadomym elementem zmiany wydaje się wyznaczanie bardziej urealnionych, uzależnionych od kontekstu celów, świadomego wyboru zadań oraz osobistego zaangażowania w definiowaniu i rozumieniu rzeczywistości. Rzecz w tym, aby nie rezygnować $\mathrm{z}$ idei stanowiących sedno edukacji artystycznej, ale nie traktować ich w sposób redukcjonistyczny, w oderwaniu od czasów i przestrzeni społecznej, w której żyją młodzi ludzie. Nikt inny, jak bezpośrednio pracujący z daną grupą nauczyciel muzyki, nie będzie potrafił lepiej nakreślić programu tego przedmiotu w szkole i konkretnych działań służących rozwojowi estetycznemu dziecka. Olbrzymią rolę w tym zakresie mogą odegrać inspirujące spotkania przedstawicieli środowiska młodzieży, artystów, praktyków i teoretyków pedagogiki. Dialog, wola przebudowy skostniałej rzeczywistości i żywotność poruszanej problematyki mogą odkryć nowe obszary badawcze, lepsze rozwiązania metodyczne, ciekawsze propozycje zajęć. Być może to wciąż za mało, jednak historia uczy nas, że to właśnie $\mathrm{w}$ drobnych, głęboko umotywowanych odśrodkowych działaniach kryje się siła ludzkiej aktywności, zdolna przynajmniej w części przeciwstawić się zagrożeniom współczesnej kultury, w tym syndromowi konsumpcyjnego stylu życia. Lecz, podobnie jak każde inne rozwiązania natury społecznej, jakiekolwiek podjęte działania czy rozstrzygnięcia w tej materii nie mogą stanowić układu zamkniętego, przyjętego raz na zawsze.

\section{Wnioski, konkluzje}

W sporym uproszczeniu mamy więc do czynienia ze skrajnymi sposobami podejścia nauczycieli wobec konsumpcjonizmu w edukacji muzycznej. Pomijając przypadki całkowitej ignorancji problemu czy też braku jego artykulacji, widoczna jest tu postawa dystansu i wychłodzenia emocjonalnego bądź frustracji w odpowiedzi na zastany obraz rzeczywistości, uznanej jako trudna, jeśli nie krytyczna. Pierwszy przypadek opisuje następująca sytuacja: w związku ze słabym zainteresowaniem uczniów wartościową kulturą muzyczną, nauczyciel w minimalny sposób nastawiony jest na zmianę swojego stylu nauczania, co wiąże się z nikłym zaangażowaniem i brakiem twórczego pedagogicznie wysiłku $\mathrm{z}$ jego strony. $\mathrm{W}$ drugim przypadku nauczyciel dostrzega symptomy kryzysu kultury, w tym niewydolność systemu szkolnictwa powszechnego w zakresie muzyki, ale skutkuje to raczej wielością mniej 
lub bardziej chaotycznych i fragmentarycznych form jego aktywności, w myśl zasady: im więcej, bardziej kolorowo i różnorodnie, tym lepiej (tu swoje „Zwodnicze żniwo” również zbiera retoryka konsumpcjonizmu). W edukacji muzycznej owa postawa przybiera niekiedy obraz pogoni za konsumowaniem okolicznościowych imprez i wydarzeń pseudoartystycznych. Być może jest w tym ukryta metoda heurystyczna, ale w takim wydaniu absolutnie mnie ona nie przekonuje. Wielość bezowocnych działań może też wypalać zawodowo nauczyciela, drastycznie obniżając poczucie sensu jego aktywności. Doświadczanie przez uczniów rozproszonych, powierzchownych inicjatyw w zakresie muzykowania spłyca $z$ kolei obraz samej natury wypowiedzi estetycznej, udaremniając kształtowanie poczucia spójności i ciągłości w pogłębianiu sposobów wyrażania siebie poprzez muzyczne środki wyrazu artystycznego, co w konsekwencji zniechęca do czynnego uprawiania muzyki. Zdrowym natomiast podejściem do praktyki pedagogicznej, ale także własnej tożsamości zawodowej, jak postuluje Andrzej Murzyn, wydaje się nieustanne pochylanie nad rozwijaniem odwagi społecznej, będącej szczególnym przypadkiem odwagi twórczej oraz osobowej (Murzyn, 2015, s. 85 i n.). Jest ona niezbędna w zachowaniu tego, co naprawdę wartościowe i ponadczasowe w powszechnej edukacji muzycznej, a zmianie tego, co się już nie sprawdza, co wyczerpało swoją formułę.

\section{BIBLIOGR AFIA}

Bauman o popkulturze. Wypisy. (2008). Wyb. M. Halawa, P. Wróbel. Warszawa: Wydawnictwa Akademickie i Profesjonalne.

Beck, U. (2009). Ponowne odkrycie polityki: przyczynek do teorii modernizacji refleksywnej. W: U. Beck, A. Giddens, S. Lash, Modernizacja refleksywna. Przekł. J. Konieczny. Warszawa: PWN.

Białkowski, A. (2012). Wprowadzenie. W: A. Białkowski (red.), Nowe obszary i drogi rozwoju edukacji muzycznej w Polsce. Warszawa: Instytut Muzyki i Tańca.

Blumer, H. (2008). Interakcjonizm symboliczny. Perspektywa i metoda. Przekł. G. Woroniecka. Kraków: Nomos.

Bourdieu P. (2005). Dystynkcja. Społeczna krytyka władzy sq̨dzenia. Przekł. P. Biłos. Warszawa: Scholar.

Burszta, W. J. (1998). Antropologia kultury. Poznań: Zysk i S-ka Wydawnictwo.

Dudzikowa, M. (2013). Użyteczność pojęcia działań pozornych jako kategorii analitycznej. Egzemplifikacje z obszaru edukacji (i nie tylko). W: M. Dudzikowa, K. Knasiecka-Falbierska (red.), Sprawcy i/lub ofiary działań pozornych w edukacji szkolnej. Kraków: Oficyna Wydawnicza „Impuls”.

Goffman, E. (2011). Człowiek w teatrze życia codziennego. Przekł. H. Datner-Śpiewak, P. Śpiewak. Warszawa: Aletheia.

Gołaszewska, M. (1979). Kultura estetyczna. Warszawa: WSiP.

Jabłońska, B. (2014). Socjologia muzyki. Warszawa: Scholar.

Klus-Stańska, D., Nowicka, M. (2005). Sensy i bezsensy wczesnej edukacji. Warszawa: WSiP. 
Konaszkiewicz, Z. (2012). Wiadomości, wiedza, mądrość w kształceniu i pracy nauczycieli muzyki. W: Z. Rondomańska, Zadania edukacji XXI wieku. Olsztyn: ZP UWM.

Lash, S. (2009). Refleksyjność i jej sobowtóry: struktura, estetyka, wspólnota. W: U. Beck, A. Giddens, S. Lash, Modernizacja refleksywna. Przekł. J. Konieczny. Warszawa: PWN.

Melosik, Z. (2007). Kultura popularna jako czynnik socjalizacji. W: Z. Kwieciński, B. Śliwerski (red.), Pedagogika. Podręcznik akademicki (t. 2). Warszawa: PWN.

Melosik, Z. (2013). Kultura popularna i tożsamość młodzieży. Kraków: Oficyna Wydawnicza „Impuls”.

Murzyn, A. (2015). Współczesna filozofia edukacji. Kraków: Oficyna Wydawnicza „Impuls”.

Przychodzińska, M. (2006). Wychowanie muzyczne w szkołach polskich z perspektywy stulecia 1900-200o. W: A. Białkowski (red.), Edukacja muzyczna. Tożsamość i praktyka. Lublin: Wyd. UMCS.

Sacher, W. A. (2012). Pedagogika muzyki. Kraków: Oficyna Wydawnicza „Impuls”.

Sztompka, P. (2012). Socjologia. Kraków: Znak.

Tatarkiewicz, W. (1975). Dzieje sześciu pojęć. Warszawa: PWN.

Terada, Y. (2004). Rozwój społeczeństwa konsumpcyjnego i różne koncepcje wolności. W: M. Golka (red.), W cywilizacji konsumpcyjnej. Poznań: Wydawnictwo Naukowe UAM.

\section{SUMMARY}

\section{Consumerism in culture and music education. An outline of the issue}

The article presents subjective and critical analysis of current music education. The analysis is based on long and meditative pedagogical experience. The most visible problem of modern musical culture is inconsistency of musical reality, in which young people live and the language of Music subject. It is mainly connected with the ignorance of characteristic modern social practices such as consumerism and inapplicability of didactic aims in music. In my opinion it is one of the main reasons of discrepancy between music curriculum and musical aspirations and interests of students. The aim of this article is to present current model of music education, indicate weaknesses of this issue and show eventual possibilities in changing the approach of young people to art music. The article is divided into a few sections, which present basic issues about music education, the recognition of symptoms of consumerism and the conclusion.

KEY WORDS: culture, consumption, music, education. 